\title{
Karakterisasi Fisiologi Beberapa Isolat Cendawan Entomopatogen Beauveria Bassiana Dan Virulensinya Terhadap Spodoptera Litura
}

\author{
Trizelia, Novri Nelly, A. Meizon Hendrik \\ Jurusan Hama dan Penyakit Tumbuhan Fakultas Pertanian Universitas Andalas Padang \\ Email : trizelia@yahoo.com
}

\begin{abstract}
ABSTRAK
Penelitian ini bertujuan untuk mempelajari karakter fisiologi isolat $B$. bassiana yang berasal dari berbagai inang dan virulensinya terhadap Spodoptera litura. Lima isolat $B$. bassiana yang diuji diisolasi dari hama Leptocorisa oratorius (F.) dan Hypothenemus hampei (Ferr.), rizosfer tanaman bawang daun buah kakao dan batang gandum. Karakter fisiologi yang diamati adalah daya kecambah konidia, pertumbuhan koloni, dan sporulasi, Cendawan diperbanyak pada media SDAY dan uji virulensi dilakukan terhadap larva instar II $S$. litura. Hasil penelitian menunjukkan bahwa daya kecambah konidia, pertumbuhan koloni dan sporulasi bervariasi antar isolat. Isolat B. bassiana yang diisolasi dari L. oratorius dan buah kakao memiliki karakter fisiologi yang lebih baik dibandingkan dengan isolat lain. Kedua isolat ini juga lebih virulen terhadap larva instar II $S$. litura dengan mortalitas sebesar $80-81,67 \%$.
\end{abstract}

Kata kunci: fisiologi, cendawan entomopatogen, Beauveria bassiana, Spodoptera litura, virulensi

\section{PENDAHULUAN}

Ulat grayak (Spodoptera litura) merupakan salah satu jenis hama penting yang menyerang tanaman palawija dan sayuran di Indonesia. Hama ini sering mengakibatkan penurunan produktivitas bahkan kegagalan panen karena menyebabkan daun menjadi robek dan buah berlubang. Bila tidak segera dikendalikan maka daun atau buah tanaman di areal pertanian akan habis (Lembaga Pertanian Sehat, 2008). S. litura menyerang tanaman budidaya pada fase vegetatif dan generatif. Pada fase vegetatif larva memakan daun tanaman yang muda sehingga tinggal tulang daun saja dan fase generatif dengan memakan polong-polong muda. Serangan $S$. litura menyebabkan kerusakan sekitar $12,5 \%$ dan lebih dari $20 \%$ pada tanaman umur lebih dari 20 hari setelah tanam. Serangan berat akan menyebabkan tanaman mati (Hennie et al., 2003; Adisarwanto dan Wudianto, 1999).

Sejauh ini pengendalian hama tanaman yang dilakukan oleh para petani, termasuk pengendalian $S$. litura masih mengandalkan insektisida kimia (Marwoto, 2008). Petani umumnya menggunakan insektisida kimia yang intensif (dengan frekuensi dan dosis tinggi). Hal ini mengakibatkan timbulnya dampak penggunaan pestisida seperti: gejala resistensi, resurjensi hama, terbunuhnya musuh alami, meningkatnya residu pada hasil, mencemari lingkungan dan gangguan kesehatan bagi pengguna (Direktorat Perlindungan Tanaman Hortikultura, 2008).

Dengan demikian perlu diupayakan pemanfaatan pestisida yang ramah terhadap lingkungan, mudah terurai di alam, tidak mencemari ekosistim serta relatif aman terhadap manusia dan ternak. Pestisida hayati (biopestisida) yang berbahan aktif mikroba (cendawan Beauveria bassiana) merupakan salah satu alternatif yang bisa dimanfaatkan untuk pengendalian hama pada usaha tani komoditi sayuran organik. Penggunaan biopestisida ini dapat mengurangi residu beracun pada produk sayuran organik sehingga aman untuk dikonsumsi.

Hasil uji laboratorium menunjukkan bahwa penggunaan $B$. bassiana dapat 
mematikan hama kubis Crocidolomia. pavonana sampai $80 \%$. Mortalitas larva sangat tergantung pada sumber isolat (Trizelia \& Nurdin 2010). B. bassiana dilaporkan efektif dalam mengendalikan beberapa jenis hama bawang merah seperti S. exigua, S. litura dan Neotoxoptera sp. (Rusli \& Trizelia, 2009; Trizelia \& Rusli, 2011; Trizelia \& Nelly, 2013).

B. bassiana terdapat di seluruh dunia dan merupakan cendawan entomopatogen yang memiliki jenis inang terbanyak diantara cendawan entomopatogen lain. Inangnya terutama adalah serangga dari ordo Lepidoptera, Coleoptera, Hemiptera, Diptera dan Hymenoptera (Tanada \& Kaya 1993). Oleh karena itu $B$. bassiana memiliki strain atau isolat yang kadangkadang tidak bisa dibedakan secara morfologi dan mempunyai karakter genetik dan fisiologi yang berbeda. Adanya keragaman dalam spesies $B$. bassiana ditunjukkan oleh adanya perbedaan patogenisitas (Hajek \& St. Leger 1994). Hasil penelitian Trizelia (2005) menunjukkan bahwa perbedaan virulensi cendawan terhadap hama kubis Crocidolomia. pavonana berhubungan dengan perbedaan sifat fisiologi antara isolat $B$. bassiana. Berdasarkan hal tersebut, maka penelitian ini bertujuan untuk mempelajari karakter fisiologi isolat $B$. bassiana yang berasal dari berbagai inang dan virulensinya terhadap Spodoptera litura.

\section{METODE PENELITIAN}

\section{Waktu dan Tempat}

Penelitian ini telah dilaksanakan dari Maret sampai Agustus 2015 di Laboratorium Pengendalian Hayati Jurusan
Hama dan Penyakit Tumbuhan, Fakultas Pertanian Universitas Andalas

\section{Metode Penelitian}

Penelitian ini menggunakan

Rancangan Acak Lengkap (RAL) yang terdiri dari 5 isolat sebagai perlakuan dan 4 ulangan. Isolat yang digunakan adalah BbTBKA5, BbLoDk, BbHhKA12, BbKT2B2 dan BbGTD3.1.2. keterangan dari masing-masing isolat dapat dilihat pada Tabel 1. Data yang diperoleh selanjutnya diolah dengan sidik ragam dan jika berbeda nyata dilanjutkan dengan uji Tukey (HSD) pada taraf nyata $5 \%$.

\section{Pelaksanaan Penelitian Koleksi dan Perbanyakan Isolat}

Isolat Beauveria bassiana yang digunakan dalam penelitian ini merupakan koleksi Laboratorium Pengendalian Hayati Jurusan HPT Fakultas Pertanian Universitas Andalas. Seluruh isolat ditumbuhkan pada medium Sabouraud Dextrose Agar + Yeast Extract (SDYA).

\section{Perbanyakan larva $S$. litura}

Larva $S$. litura dikumpulkan dari pertanaman bawang daun/kubis di lapangan dan dipelihara dalam kotak plastik serta diberi makanan berupa daun bawang/kubis yang masih segar. Makanan larva diganti jika habis atau sudah tidak segar lagi.

Larva-larva tersebut dipelihara sampai membentuk pupa dan imago. Selanjutnya imago yang diperoleh dimasukkan ke dalam kurungan serangga yang telah berisi tanaman bawang daun/kubis sebagai tempat peletakkan telur. Sebagai makanan imago digunakan madu dengan konsentrasi $10 \%$. Kelompok telur yang diletakkan

Tabel 1 Sumber isolat B. bassiana yang digunakan

\begin{tabular}{|c|c|c|}
\hline Isolat & Sumber inang & Lokasi \\
\hline BbTBKA5 & Tanah Bawang daun & Kayu Aro(Solok) \\
\hline BbLoDk & $\begin{array}{l}\text { Leptocorisa oratorius (F.) (Hemiptera: } \\
\text { Coreidae) }\end{array}$ & Duku (Padang Pariaman) \\
\hline BbHhKA12 & $\begin{array}{l}\text { Hypothenemus hampei (Ferr.) } \\
\text { (Coleoptera: Scolytidae) }\end{array}$ & Kayu Aro (Solok) \\
\hline BbКT2B2.2 & Buah Kakao & Kayu Tanam (Padang Pariaman) \\
\hline BbGTD3.1.2 & Batang Gandum & Koto Laweh (Tanah Datar) \\
\hline
\end{tabular}


dipindahkan ke kotak plastik lain dan dipelihara sampai telur menetas.

\section{Persiapan Suspensi Konidia}

Seluruh isolat diperbanyak pada media SDAY dalam cawan petri pada suhu $25^{\circ} \mathrm{C}$ selama 15 hari. Konidia cendawan dipanen dengan cara menambahkan $5 \mathrm{ml}$ akuades steril dan $0.05 \%$ Tween 80 sebagai bahan perata ke dalam cawan Petri dan konidia dilepas dari media dengan kuas halus. Suspensi disaring dan konsentrasi konidia dihitung dengan menggunakan hemositometer.

\section{Pengamatan \\ Evaluasi Daya Kecambah Konidia}

Daya kecambah konidia ditentukan menurut metode yang dikemukakan oleh Junianto \& Sukamto (1995). Medium SDAY yang berbentuk lempengan dengan ukuran luas sekitar $1 \mathrm{~cm}^{2}$ dan tebal 1-2 mm diletakkan di atas gelas objek steril. Di atas medium diteteskan $10 \mu \mathrm{l}$ suspensi konidia yang mengandung $10^{6}$ konidia $/ \mathrm{ml}$ dan dimasukkan ke dalam cawan Petri steril yang diisi dengan kertas saring lembab dan diinkubasikan Pengamatan menggunakan mikroskop cahaya dengan perbesaran 400 kali. Persentase kecambah dihitung dari 100 konidia. Konidia dinyatakan berkecambah apabila panjang tabung kecambah telah melebihi diameter konidia.

\section{Laju Pertumbuhan Koloni}

Potongan miselium dengan agar dari masing-masing isolat yang telah berumur 7 hari dengan diameter $10 \mathrm{~mm}$ diinokulasikan pada media SDAY dalam cawan Petri dan diinkubasikan pada suhu $25^{\circ} \mathrm{C}$. Diameter koloni dari masing-masing isolat diukur setiap 5 hari sampai hari ke 20.

\section{Sporulasi}

Untuk menghitung sporulasi masing-masing isolat dilakukan dengan cara menyiapkan suspensi konidia dengan konsentrasi $10^{5} \mathrm{konidia} / \mathrm{ml}$. Untuk masingmasing isolat, $0.1 \mathrm{ml}$ suspensi konidia dimasukkan dalam cawan Petri (berukuran $9 \mathrm{~cm}$ ) yang telah berisi media SDAY.
Biakan diinkubasikan selama 21 hari pada suhu $25^{\circ} \mathrm{C}$. Setelah 15 hari, biakan pada cawan Petri dimasukkan ke dalam labu Erlenmeyer dan ditambahkan $50 \mathrm{ml}$ akuades steril. Biakan divorteks selama 5 menit, disaring dan diencerkan sampai 4 kali. Konsentrasi konidia dari suspensi dihitung dengan hemositometer dan ratarata jumlah konidia per cawan Petri dibandingkan antar isolat.

\section{Uji Patogenisitas}

Instar larva $S$. litura yang diuji adalah larva instar II yang berumur satu hari. Konsentrasi konidia dari masingmasing isolat yang digunakan adalah $10^{8}$ konidia/ml. Inokulasi cendawan dilakukan dengan cara menyemprotkan suspensi konidia pada bagian dorsal tubuh larva dengan menggunakan handsprayer. Larva kemudian diberi makan dengan daun kubis segar. Satuan percobaan terdiri dari 10 ekor larva. Mortalitas larva diamati setiap hari hingga tujuh hari setelah aplikasi cendawan.

\section{HASIL DAN PEMBAHASAN}

\section{A. Hasil}

\section{Daya Kecambah Konidia}

Hasil penelitian menunjukkan bahwa daya kecambah konidia antar isolat $B$. bassiana berbeda nyata (Tabel 2). Isolat BbLoDk memiliki daya kecambah konidia tertinggi $(89.00 \%)$ dibandingkan dengan isolat lain dan isolat BbKT2B2.2 memiliki daya kecambah konidia paling rendah, yaitu

Tabel 2. Rata-rata daya kecambah konidia berbagai isolat $B$. bassiana

\begin{tabular}{lc}
\hline Isolat & $\begin{array}{c}\text { Daya Kecambah konidia } \\
(\%) \pm \mathrm{SD}\end{array}$ \\
\hline BbLoDk & $89.00 \pm 2.71 \mathrm{a}$ \\
BbHhKA12 & $78.00 \pm 3.16 \mathrm{~b}$ \\
BbGTD3.1.2 & $75.00 \pm 2.45 \mathrm{~b}$ \\
BbTBKA5 & $74.31 \pm 1.98 \mathrm{~b}$ \\
BbKT2B2.2 & $63.90 \pm 2.62 \mathrm{c}$ \\
\hline Angka yang diikuti huruf yang sama pada \\
kolom yang sama tidak berbeda nyata \\
menurut uji Tukey (HSD) pada taraf nyata \\
5\%..
\end{tabular}


$63.90 \%$. Isolat yang memiliki daya kecambah konidia yang tinggi akan mempunyai peluang yang besar untuk bisa menimbulkan infeksi dan mematikan serangga uji.

\section{Pertumbuhan Koloni}

Hasil pengamatan terhadap pertumbuhan koloni berbagai isolat $B$. bassiana setelah 20 hari masa inkubasi memperlihatkan perbedaan yang nyata (Tabel 3). Isolat BbLoDk, BbKT2B2.2, dan BbTBKA5 mempunyai pertumbuhan koloni yang lebih cepat dibandingkan dengan isolat lain. Dalam waktu 20 hari diameter koloni telah mencapai lebih dari 8 $\mathrm{cm}$

Tabel. 3 Rata-rata diameter koloni berbagai isolat $B$. bassiana setelah 20 hari masa inkubasi dalam suhu ruang.

\begin{tabular}{lc}
\hline Isolat & $\begin{array}{c}\text { Diameter koloni } \\
(\mathrm{cm}) \pm \mathrm{SD}\end{array}$ \\
\hline BbLoDk & $8.745 \pm 0.11 \mathrm{a}$ \\
BbKT2B2.2 & $8.575 \pm 0.29 \mathrm{a}$ \\
BbTBKA5 & $8.500 \pm 0.21 \mathrm{a}$ \\
BbGTD3.1.2 & $6.682 \pm 1.24 \mathrm{~b}$ \\
BbHhKA12 & $6.270 \pm 0.55 \mathrm{~b}$ \\
\hline Angka yang diikuti huruf yang sama pada \\
kolom yang sama tidak berbeda nyata \\
menurut uji Tukey (HSD) pada taraf nyata \\
5\%..
\end{tabular}

\section{Sporulasi}

Jumlah konidia yang dihasilkan masing-masing isolat setelah 15 hari masa inkubasi memperlihatkan hasil yang berbeda nyata. Isolat BbLoDk memiliki kemampuan sporulasi yang tertinggi yaitu mampu menghasilkan konidia sebanyak $17.75 \times 10^{8} \mathrm{konidia} / \mathrm{ml}$ dan berbeda nyata dengan isolat yang lain (Tabel 4). Isolat yang akan dipilih sebagai agens pengendali hayati harus memiliki kemampuan menghasilkan konidia yang tinggi, karena konidia sangat penting untuk infeksi dan pemencaran cendawan
Tabel 4. Jumlah konidia yang diproduksi selama 21 hari masa inkubasi dalam suhu ruang.

\begin{tabular}{lc}
\hline Isolat & $\begin{array}{c}\text { Jumlah konidia/ml }\left(\times 10^{8}\right) \\
\pm \mathrm{SD}\end{array}$ \\
\hline BbLoDk & $17.75 \pm 2.50 \mathrm{a}$ \\
BbGTD3.1.2 & $17.00 \pm 3.68 \mathrm{a}$ \\
BbTBKA5 & $15.25 \pm 1.93 \mathrm{a}$ \\
BbKT2B2.2 & $10.50 \pm 2.94 \mathrm{ab}$ \\
BbHhKA12 & $7.75 \pm 3.72 \mathrm{~b}$ \\
\hline
\end{tabular}

Angka yang diikuti huruf yang sama pada kolom yang sama tidak berbeda nyata menurut uji Tukey (HSD) pada taraf nyata $5 \%$.

\section{Mortalitas Larva S. litura}

Hasil penelitian menunjukkan bahwa isolat $B$. bassiana yang berasal dari geografi dan inang yang berbeda mempunyai virulensi yang berbeda nyata terhadap larva $S$. litura instar II. Isolat BbLoDk merupakan isolat yang paling virulen dengan rata-rata mortalitas larva tertinggi yaitu $81.67 \%$ pada pengamatan hari ketujuh setelah aplikasi konidia, berbeda tidak nyata dengan isolat BbKT2B2.2 dengan mortalitas larva $80 \%$. Isolat BbTBKA5 merupakan isolat yang mempunyai kategori virulensi sangat rendah dengan mortalitas 36.66\% (Tabel 5).

Tabel 5. Mortalitas larva $S$. litura instar II tujuh hari setelah aplikasi 5 isolat B. bassiana pada konsentrasi $10^{8}$ konidia/ml.

\begin{tabular}{ll}
\hline Isolat & Mortalitas (\%) $\pm \mathrm{SD}$ \\
\hline BbLoDk & $81.67 \pm 6.39 \mathrm{a}$ \\
BbKT2B2.2 & $80.00 \pm 5.45 \mathrm{a}$ \\
BbHhKA12 & $55.00 \pm 14.78 \mathrm{~b}$ \\
BbGTD3.1.2 & $47.50 \pm 8.77 \mathrm{bc}$ \\
BbTBKA5 & $36.66 \pm 3.85 \quad \mathrm{c}$ \\
Kontrol & $1.67 \pm 3.33 \quad \mathrm{~d}$ \\
\hline Antal
\end{tabular}

Angka yang diikuti huruf yang sama pada kolom yang sama tidak berbeda nyata menurut uji Tukey (HSD) pada taraf nyata $5 \%$.

Berdasarkan nilai $\mathrm{LT}_{50}$ terlihat ada perbedaan antar isolat (Tabel 6) dan perbedaan nilai $\mathrm{LT}_{50}$ berkaitan dengan virulensi isolat. Nilai $\mathrm{LT}_{50}$ B. bassiana berkisar antara 5.18 hari -10.20 hari. 
Isolat BbKT2B2.2 dan BbLoDk memiliki nilai $\mathrm{LT}_{50}$ tersingkat dibandingkan dengan isolat lain (5.18 dan 5.31 hari)

Tabel 6. Nilai $\mathrm{LT}_{50}$ berbagai isolat $B$. bassiana.

\begin{tabular}{ll}
\hline Isolat & LT $_{50}(\mathrm{SK} 95 \%)($ hari $)$ \\
\hline BbLoDk & $5.31(4.25-7.36)$ \\
BbKT2B2.2 & $5.18(4.35-6.35)$ \\
BbHhKA12 & $7.02(6.40-8.32)$ \\
BbGTD3.1.2 & $7.86(6.78-10.43)$ \\
BbTBKA & $10.20(7.68-18.91)$ \\
\hline
\end{tabular}

\section{Pembahasan}

Adanya variasi daya kecambah setiap isolat diduga disebabkan oleh adanya perbedaan kebutuhan nutrisi dari masingmasing isolat. Menurut Tanada dan Kaya (1993) dan Hatzipapas et al. (2002) perkecambahan konidia sangat tergantung pada kondisi lingkungan seperti kelembaban, suhu dan cahaya serta nutrisi. Pemicu perkecambahan berhubungan dengan ada atau tidak adanya serta konsentrasi nutrisi di luar konidia yang berhubungan dengan karakteristik permukaan spesies inang dari mana isolat tersebut diperoleh. Taborsky (1992) mengemukakan bahwa kebutuhan nutrisi untuk pertumbuhan cendawan entomopatogenik sangat bervariasi tergantung pada spesies dan strain cendawan. Menurut Leland (2001) evaluasi daya kecambah konidia cendawan entomopatogen perlu dilakukan terutama apabila cendawan tersebut akan dikembangkan sebagai bioinsektisida. Dalam pemilihan isolat yang akan digunakan, kecepatan perkecambahan konidia juga harus diperhitungkan. Isolat yang berkecambah lebih cepat lebih berpotensi untuk menimbulkan infeksi, karena isolat ini akan terhindar dari pengaruh kekeringan, pengaruh dari mikroorganisme lain dan terlepas dari kutikula serangga pada waktu ekdisis.

Isolat $B$. bassiana yang tumbuh lebih cepat lebih menguntungkan dalam penggunaannya sebagai agens pengendali hayati. Hal ini disebabkan karena lebih sedikit waktu yang dibutuhkan untuk memperbanyak cendawan, lebih mampu bersaing dengan mikroorganisme lain dan lebih cepat untuk menimbulkan infeksi pada serangga. Hasil penelitian Kassa (2003) menunjukkan adanya perbedaan pertumbuhan koloni antar isolat $B$. bassiana yang dikoleksi dari berbagai daerah di Ethiopia dan Sudan, tetapi hasil penelitian Varela dan Morales (1996) menunjukkan bahwa pertumbuhan koloni antar isolat $B$. bassiana tidak berbeda nyata Bidochka et al. (2000) mengemukakan bahwa cendawan entomopatogen $B$. bassiana yang ditumbuhkan pada medium kompleks seperti PDA akan mampu menghasilkan konidia lebih dari $10^{9}$ konidia/cawan Petri dan kemampuan menghasilkan konidia akan bervariasi tergantung pada isolat. Isolat yang mampu bersporulasi dengan baik lebih menguntungkan karena isolat tersebut mampu menimbulkan epizootik dalam waktu yang lebih pendek dan untuk perbanyakan dengan tujuan produksi bioinsektisida membutuhkan jumlah inokulum yang lebih sedikit (Varela dan Morales 1996). Apabila sporulasi sedikit, maka pemencaran B. bassiana akan terbatas dan kemampuannya sebagai agens pengendali hayati juga akan berkurang (Junianto dan Sukamto 1995).

Adanya perbedaan virulensi dari 5 isolat $B$. bassiana yang diuji diduga disebabkan karena adanya perbedaan karakter fisiologi antar isolat seperti daya kecambah konidia,laju pertumbuhan koloni, kemampuan bersporulasi dan metabolisme sekunder yang dihasilkan yaitu berupa kemampuan menghasilkan enzim dan toksin dan karakter genetik. Hasil penelitian Trizelia (2005) menunjukkan bahwa perbedaan virulensi antar isolat $B$. bassiana terhadap larva $C$. pavonana disebabkan oleh adanya perbedaan karakter fisiologi dan genetik dari isolat. Selanjutnya Geden et al. (1995) mengemukakan bahwa adanya perbedaan virulensi isolat $B$. bassiana terhadap Musca domestica Linn. (Diptera: Muscidae) disebabkan oleh adanya perbedaan kemampuan daya kecambah konidia dari masing-masing isolat dan daya kecambah konidia merupakan salah satu faktor penentu virulensi. Tanada dan Kaya (1993) selanjutnya mengemukakan bahwa adanya perbedaan virulensi antar isolat 
disebabkan karena adanya perbedaan kemampuan menghasilkan enzim dan mikotoksin selama berjalannya proses infeksi pada serangga seperti pada saat kontak dengan kutikula dan di dalam hemosoel. Isolat yang virulen memiliki aktivitas enzim yang lebih tinggi dibandingkan dengan isolat yang avirulen. Isolat BbKT2B2.2 dan BbLoDk memiliki nilai $\mathrm{LT}_{50}$ tersingkat dibandingkan dengan isolat lain (5.18 dan 5.31 hari) dan hal ini berarti bahwa waktu yang dibutuhkan untuk mematikan 50\% larva $S$. litura lebih singkat dibandingkan dengan isolat lain. Neves dan Alves (2004) mengemukakan bahwa waktu kematian serangga dipengaruhi oleh dosis aplikasi dan virulensi dari isolat. Adanya perbedaan nilai $\mathrm{LT}_{50}$ antar isolat $B$. bassiana juga dilaporkan oleh Junianto dan Sulistyowati (1994) yang mengemukakan isolat $B$. bassiana yang virulen terhadap $H$. hampei (Bb-704) lebih cepat mematikan imago dengan nilai $\mathrm{LT}_{50}$ yang lebih pendek yaitu 4.6 hari daripada isolat yang avirulen $(\mathrm{Bb}-$ 706) yang memiliki nilai $\mathrm{LT}_{50} 7.1$ hari. Trizelia (2005) melaporkan isolat $B$. bassiana yang virulen terhadap Crocidolomia pavonana (Bb-Cp) lebih cepat mematikan larva dengan nilai $\mathrm{LT}_{50}$ yang lebih pendek yaitu 5.69 hari daripada isolat yang avirulen $(\mathrm{Bb}-\mathrm{Cc})$ yang memiliki nilai $\mathrm{LT}_{50} 8.20$ hari.

\section{KESIMPULAN}

Karakter fisiologi dari lima isolat $B$. bassiana bervariasi antar isolat, baik pada daya kecambah konidia, pertumbuhan koloni maupun sporulasi. Isolat BbLoDk memiliki karakter fisiologi yang lebih baik dibandingkan dengan isolat lain. Hasil uji virulensi terhadap larva $S$. litura juga menunjukkan bahwa isolat BbLoDk mampu mematikan larva sampai $81.67 \%$ dengan nilai nilai $\mathrm{LT}_{50} 5.31$ hari

\section{UCAPAN TERIMA KASIH}

Melalui kesempatan ini penulis menyampaikan penghargaan dan terima kasih kepada Direktorat Jenderal Pendidikan Tinggi, Kementerian Riset,
Teknologi dan Pendidikan Tinggi sesuai dengan Surat Perjanjian Pelaksanaan Hibah Penelitian Nomor 030/SP2H/PL/ DIT.LITABMAS/II/2015 tanggal 5 Februari 2015 yang telah membantu pendanaan penelitian ini sehingga penelitian ini dapat berjalan dengan lancar.

\section{DAFTAR PUSTAKA}

Adisarwanto T., R. Wudianto. 1999. Meningkatkan Hasil Panen Kedelai di Lahan Sawah Kering, Pasang Surut.Penebar Swadaya: Jakarta

Bidochka MJ, AM Kamp, JNA de Croos. 2000. Insect pathogenic fungi: from genes to populations. Di dalam: Kronstad JW, editor. Fungal Pathology. Netherlands; Kluwer Academic Publishers. Hlm 171193.

Direktorat Perlindungan Tanaman Hortikultura. 2008. Pengenalan dan Pengendalian Hama Tanaman Sayuran Prioritas. Direktorat Perlindungan Tanaman Hortikultura: Jakarta.

Geden CJ, DA Rutz, DC Steinkraus. 1995. Virulence of different isolates and formulations of Beauveria bassiana for house flies and the parasitoid Muscidifurax raptor. Biol Contr 5:615-621.

Hajek AE, RJ St. Leger. 1994. Interactions between fungal pathogens and insect hosts. Annu Rev Entomol 39:293-322.

Hatzipapas P, K K alosaka, A Dara, C Christias. 2002. Spore germination and appressorium formation in the entomopathogenic Alternaria alternata. Mycol Res 106(11): 1349-1359.

Hennie. J Laoh., F. Puspita, Hendra. 2003. Kerentanan Larva Spodoptera litura F terhadap Virus Nuklear Polyhedrosis. Jurnal Natur Indonesia. http://www.unri.ac.id/ jurnal/jurnal nature $/ \operatorname{vol5}(2) \quad[25$ Februari 2009]. 
Junianto YD, S Sukamto. 1995. Pengaruh suhu dan kelembaban relatif terhadap perkecambahan, pertumbuhan dan sporulasi beberapa isolat $B$. bassiana. Pelita Perkebunan 11(2):64-75.

Junianto YD, E Sulistyowati. 1994. Virulence of several Beauveria bassiana Bals. Vuill. isolates on coffee berry borer (Hypothenemus hampei Ferr.) under various relative humidities. Pelita Perkebunan 10(2):81-86.

Kassa A. 2003. Development and testing of mycoinsecticides based on submerged spores and aerial conidia of the entomopathogenic fungi Beauveria bassiana and Metarhizium anisopliae (Deuteromycotina: Hyphomcete) for control of locusts, grasshoppers and storage pests. [Dissertation]. Gottingen: $\quad \mathrm{hlm}$. 74-90. http//wcbdoc.sub.gwdg.de/diss/ 2003/kassa/kassa.pdf. [11 Oktober 2004].

Leland JE. 2001. Environmental-stress tolerant formulation of Metarhizium anisopliae var. acridum for control of African desert locust (Schistocerca gregaria). [Dissertation]. Blacksburg, Virginia: Faculty of Virginia Polytechnic Institute and State University. http://scholar.lib. vt.edu/theses/available/etd_120520 01_115455/unrestricted/Jleland'Dis sertation.PDF. [11 Oktober 2004].

Lembaga Pertanian Sehat | Develop Useful Innovation for Farmers. 2008. Virus Patogen Serangga: BioInsektisida Ramah Lingkungan. http://www.pertaniansehat.or.id/?pi lih=news\&aksi=lihat\&id=19. $\quad[11$ Oktober 2008].

Marwoto, S. 2008. Strategi dan Komponen Teknologi Pengendalian Ulat Grayak (Spodoptera litura fabricius) pada Tanaman Kedelai. Jurnal Litbang Pertanian 27 (4): Malang. www.pustaka-deptan.go.id publikasi/p3274083.pdf.
Neves PMOJ, SB Alves. 2004. External events related to the infection process of Cornitermes cumulans (Kollar) (Isoptera: Termitidae) by the entomopathogenic fungi Beauveria bassiana and Metarhizium anisopliae. Neotropical Entomology 33(1): 051-056.

Rusli R Trizelia. 2009. Perbanyakan Beauveria Bassiana Pada Limbah Organik, Formulasi Dan Uji Efektivitasnya Sebagai Bioinsektisida Untuk Pengendalian Hama Spodoptera Exigua Hubner (Lepidoptera: Noctuidae). Laporan Penelitian Hibah Strategis Nasional

Taborsky V. 1992. Small Scale Processing of Microbial Pesticides. FAO Agricultural Services Bulletin No. 96. Rome: Food and Agriculture of the United Nations Rome.

Tanada Y, HK Kaya. 1993. Insect Pathology. San Diego: Academic Press, INC. Harcourt Brace Jovanovich, Publisher.

Trizelia. 2005. Cendawan Entomopatogen Beauveria bassiana (Bals) Vuil. (Deuteromycotyna: Hypomycetes). Keanekaragaman Genetik, Karekteristik Fisiologi, dan Virulensinya terhadap Crocidolomia pavonana (F). [Disertasi]. Bogor. Sekolah Pasca Sarjana Institut Pertanian Bogor.

Trizelia, F Nurdin. 2010. Virulence of Entomopathogenic Fungus Beauveria bassiana isolates to Crocidolomia pavonana $\mathrm{F}$ (Lepidoptera: Crambidae) Jurnal Agrivita 32(3): 254-260.

Trizelia, R Rusli. 2011. Kompatibilitas Cendawan Beauveria bassiana dan Minyak Serai Wangi untuk Pengelolaan Terpadu Hama Crocidolomia pavonana dan Spodoptera litura pada Sayuran Organik. Laporan Penelitian Hibah Strategis Nasional DIKTI 
Trizelia et al. Karakterisasi Fisiologi Beberapa Isolat

Trizelia, N Nelly. 2013. Virulensi Beberapa Isolat Beauveria bassiana terhadap

Kutu Daun,Neotoxoptera sp. (Homoptera: Aphididae) pada Tanaman Bawang. J. Fitomedika 9 (3): $9-14$
Varela A, E Morales. 1996. Characterization of some Beauveria bassiana isolates and their virulence toward the coffee berry borer Hypothenemus hampei. $J$ Invertebr Pathol 67:147-152. 